УДК 02 : $004+37: 001.32$

Яцишин Анна Володимирівна, кандидат педагогічних наук, старший науковий співробітник, докторант, Інститут інформаційних технологій i засобів навчання НАПН України, м. Київ, е-mail: anna13.00.10@gmail.com.

\title{
МІСЦЕ І РОЛЬ МЕРЕЖІ ЕЛЕКТРОННИХ БІБЛІОТЕК УСТАНОВ НАПН УКРАЇНИ В НАУКОВО-ОСВІТНЬОМУ ПРОСТОРІ
}

\begin{abstract}
Анотація
У статті проаналізовано критерії оцінювання наукових електронних бібліотек, розглянуті різні погляди науковців на перелік цих критеріїв. Описано, що критеріями оцінювання електронної бібліотеки можуть служити: користувачі і їхні інформаційні потреби, характер інформаційних ресурсів, функціональні можливості, характер i зміст інформаційних ресурсів. Визначено особливості, що вимагають особливого підходу до розробки наукових електронних бібліотек. Зазначено, що створення мережі електронних бібліотек установ НАПН України є одним із пріоритетних напрямків розвитку науки й освіти, і $є$ першочерговим завданням від глави держави. Коротко представлено вже впроваджену електронну бібліотеку НАПН України. Визначено місце і роль мережі електронних бібліотек установ НАПН України в науково-освітньому просторі.

Ключові слова: електронна бібліотека, особливості наукових електронних бібліотек, НАПН України, науково-освітній простір.

Постановка проблеми. Характерною рисою нинішнього етапу розвитку суспільства $є$ те, що інформація стає одним 3 основних економічних ресурсів i вагомим соціальним фактором, під впливом якого змінюються форми економічної діяльності і соціальні взаємини. На сьогоднішній день інформація/відомості/дані існують як у традиційній друкованій, так i в електронній формі. «...Сучасні інформаційні технології дозволили не тільки приступити до широкомасштабного перекладу накопиченої людством інформації в електронну форму, але і до створення великої кількості нових інформаційних ресурсів відразу в електронному вигляді.
\end{abstract}


Інформатизація, конвергенція інформаційно-комунікаційних технологій i мультимедіа, перехід до застосування сучасних інформаційних систем у сфері науки і освіти забезпечують принципово новий рівень отримання й узагальнення знань, їх поширення і використання» [10].

Аналіз останніх досліджень і публікацій. Хохлов Ю. Е. підкреслює, що одним із найперспективніших способів інформаційного забезпечення науки, культури та освіти нині є використання електронних бібліотек - розподілених інформаційних систем, що дозволяють надійно накопичувати, зберігати й ефективно використовувати різноманітні колекції електронних документів, доступних в зручному для користувачів вигляді через глобальні мережі передавання даних [13].

Як зазначає Лапо П. М. «Розвиток електронних бібліотек багато в чому буде визначатися здатністю окремих людей і організацій знаходити шляхи адекватного використання технологій електронних бібліотек, засвоювати і приймати неминучі зміни i створювати необхідні соціальні умови. Створенням інформації/відомостей/даних займаються багато, але кожен привносить свій досвід, знання та ресурси» [9]. Рівень технологій, електронні бібліотеки залежать від людей і не можуть бути створені швидше, ніж можуть адаптуватися люди й організації. Це відноситься і до творців, і до користувачів, і до персоналу електронних бібліотек. У довгостроковій же перспективі жодних бар'єрів для електронних бібліотек і електронних видань немає. Технічні, економічні, соціальні та законодавчі труднощі є, але вони поступово вирішуються. Ми не можемо бути впевненими в остаточній формі, яку приймуть електронні бібліотеки, але очевидно, що вони є і будуть [9].

На сьогоднішній день важливим $є$ питання створення наукових електронних бібліотек і позиціонування їх як одного 3 основних елементів інфраструктури інформаційного суспільства або суспільства знань. Адже функції і роль електронної бібліотеки часто недооцінюються. Хохлов Ю. Е. стверджує, що люди мало замислюються над тим, що буде $з$ тим новим контентом, який був «народжений в цифрі» і якого не існує в традиційній формі. Особи, що приймають рішення на рівні великих корпорацій, окремих регіонів і цілих країн часто недооцінюють роль цифрового контенту, ідеальним інструментом, для зберігання якого є ЕБ. Але ця проблема рано чи пізно виникне, і для іï розв'язання потрібні об'єднані зусилля розрізнених спільнот, що використовують електронні бібліотеки [13]. 
Провідні зарубіжні країни вже розгорнули широкомасштабну діяльність для реалізації програм і проектів щодо створення і використання наукових електронних бібліотек на національному рівні. Впроваджуючи сучасні інформаційнокомунікаційні технології в усі галузі фундаментальних наукових досліджень, саме, створення наукових електронних бібліотек, які дозволять забезпечити швидкий доступ до даних/відомостей, розосереджених в різних країнах і різних сховищах інформації, $є$ надзвичайно важливим напрямом [10].

Різні аспекти щодо створення і функціонування електронних бібліотек розкриті у роботах авторів: Абросімова А. Г. [1], Арнаутова С. А. [2], Лапо П. М. [9], Когаловського М. Р. [8] та ін. Питання створення електронної бібліотеки НАПН України висвітлено у працях: Іванової С. М. [7], Новицького О. В. [12], Савченко 3. В. [11], Спіріна О. М. [12], Яцишин А. В. [14; 15] та ін. Проте замало розглянуті проблеми, пов'язані з визначенням ролі мережі електронних бібліотек устнов НАПН України, й особливості, що вимагають особливого підходу до розробки наукових електронних бібліотек і питання, що стосуються створення мережі електронних бібліотек НАПН України, тому дана публікація є актуальною.

Метою статті $\epsilon$ визначити місце і роль мережі електронних бібліотек установ НАПН України в науково-освітньому просторі, проаналізувати критерії оцінювання наукових електронних бібліотек.

Виклад основного матеріалу дослідження. На сьогоднішній день із різноманітних електронних бібліотек виокремлюють академічні (наукові) репозитарії й електронні архіви. Академічними репозитаріями називають зібрання матеріалів наукових установ (книжки, статті, дисертації, тези тощо). Академічні репозитарії, на відміну від комерційних видавництв наукової літератури, часто надають доступ до своїх матеріалів усім охочим 3 мінімальними обмеженнями чи взагалі без них (відкритий доступ) [4]. Більшість електронних бібліотек тематичні - такий підхід до створення набагато простіший, він дозволяе організувати просту структуру бібліотеки, обмежитися вибором однієї схеми метаданих і, відповідно, обійтися більш простим програмним забезпеченням. Найпоширенішими $\epsilon$ наукові електронні бібліотеки [1, с. 13-14].

Аналізуючи поняття «відкритий доступ», робимо висновок, що це необмежений доступ до освітніх і наукових матеріалів за допомогою комп’ютерних 
технологій (мережі Інтернет). Існує міжнародний рух, що має на меті забезпечення відкритого доступу для всіх членів суспільства до освітніх ресурсів, культурного надбання, результатів наукових досліджень. Рух відкритого доступу у науковій i освітній спільноті набуває широких масштабів з початку 1990-х років із поширенням комп’ютерів й Інтернету, що забезпечило технічні можливості для реалізації принципу відкритого доступу на якісно новому рівні. На жаль, на практиці доступ до освітніх і наукових матеріалів $є$ певною мірою обмеженим. У переважній більшості випадків це зумовлюється соціальними чинниками (політика обмеження доступу приватних або державних освітніх i наукових установ, видавництв, цифрових ресурсів тощо). Незважаючи на це, з появою електронних бібліотек, має місце чітка тенденція до зростання ступеня відкритості інформаційних ресурсів [4].

Тому, важливими задачами створення наукових електронних бібліотек є:

- доступ до результатів фундаментальних наукових досліджень широкому колу дослідників/науковців;

- забезпечення науковцям можливості швидкого доступу до численних і нових інформаційних ресурсів, нових даних/відомостей;

- створення нових технологій наукових досліджень й інструментарію для їх проведення;

- збереження цінних наукових результатів/даних для майбутніх учених;

- створення можливостей для міжнародної наукової співпраці [10; 1].

Аналізуючи вже існуючі наукові електронні бібліотеки, виникає питання чи є у наукових електронних бібліотек особливості, що вимагають особливого підходу до їх розробки? Щоб відповісти на поставлене запитання, потрібно розглянути різні погляди науковців на критерії оцінювання наукових електронних бібліотек i визначити ці особливості.

За Кімовим С. І., Слізаровим А. М. [10], критеріями оцінювання можуть служити: користувачі і їхні інформаційні потреби, характер інформаційних ресурсів, функціональні можливості електронних бібліотек, характер і зміст інформаційних ресурсів. Виділимо особливості наукових електронних бібліотек відповідно 3 наведеними критеріями.

Користувачі і їхні інформаційні потреби:

- вибагливі користувачі; 
- регламентуються інформаційні потреби;

- д динамічний характер інформаційних потреб;

- прагнення користувачів до співпраці;

- необхідність обміну інформацією;

- багатомовне середовище наукового співтовариства;

- різноманітність предметів дослідження і технологій наукового дослідження;

- демократичність наукового співтовариства [10]. Функиії наукових електронних бібліотек:

- зберігання й актуалізація колекцій інформаційних ресурсів;

- підтримка взаємозв'язків інформаційних ресурсів;

- забезпечення доступу користувачів до колекцій;

- підтримка метаданих, у тому числі каталогів колекцій;

- формування колекцій (оцифрування, реєстрація результатів спостережень й експериментів безпосередньо в процесі їх проведення);

- інтеграція видавничих технологій і технологій формування колекцій;

- підтримка різних відомостей про користувачів;

- надання різних вбудованих або надбудованих сервісів-додатків, що перетворюють електронні бібліотеки в дослідницький майданчик (віртуальна обсерваторія, віртуальна хімічна або біологічна лабораторія тощо) [10].

Характер інформачійних ресурсів: неоднорідність інформаційних ресурсів у різних аспектах - текст, статичні зображення, числові дані, відео, аудіо, мультимедіа; використання даних на різних рівнях абстракції.

Зміст інформаиійних ресурсів наукових:

- публікації в різних формах (статті, доповіді, монографії, звіти, дисертації, автореферати та ін.);

- бібліографічна інформація;

- персоналія;

- подієва інформація (календар конференцій тощо);

- результати i показники/дані різноманітних експериментів, спостережень, вимірювань;

- моделі досліджуваних процесів, явищ, феноменів, що представлені в різноманітних формах; 
- різноманітні наукові колекції і їх елементи;

- каталоги колекцій i опису їх елементів, класифікатори та інші засоби систематизації [10].

За Абросімовим А. Г., щоб визначити особливості наукових електронних бібліотек, розглянемо такі критерії оцінювання: сфера застосування; функціональні можливості; характер і зміст інформаційних ресурсів; використані методи і технології [1, c. 14].

Сфера застосування, цілі створення $i$ користувачі наукових електронних бібліотек.

Сфера застосування наукових електронних бібліотек не обмежується забезпеченням наукових досліджень, а викладання більшості навчальних дисциплін зобов'язане спиратися на останні наукові досягнення. Отже, наукові електронні бібліотеки представляють серйозний інтерес і для освіти. Це й визначає користувачів наукових електронних бібліотек - від студентів (переважно старших курсів) до викладачів і наукових співробітників - користувачів, інформаційні потреби яких носять динамічний характер [1, с. 14]. Вагомий вплив на специфіку застосування і на цілі створення наукових електронних бібліотек робить те, що наукове товариство завжди прагнуло до широкого співробітництва, усвідомлювало необхідність обміну інформацією, незважаючи на різноманітність предметів дослідження, різноманітність технологій наукових досліджень. Демократичність наукового співтовариства є однією 3 основних причин успішного розвитку наукових електронних бібліотек i, як наслідок, під час створення наукової електронної бібліотеки необхідно враховувати багатомовне середовище наукового співтовариства, неоднорідність інформації, надавати можливість оперування даними на різних рівнях абстракції [1, с. 15].

Однією 3 проблем, яка $є$ спільною для спільноти людей, що створюють i використовують електронні бібліотеки, є питання вибору загальних способів подання цифрового контенту для забезпечення доступу до нього, а також загальних стандартів для створення відповідних механізмів взаємодії. Ті стандарти, які вироблені окремою спільнотою, наприклад співтовариством бібліотекарів, i стандарти, які використовуються спільнотами дослідників, що створюють електронні бібліотеки, достатньо сильно розрізняються, і це є серйозною перешкодою на шляху успішного впровадження і використання електронних бібліотек [13]. 
Властивості наукових електронних бібліотек. Наукові електронні бібліотеки охоплюються практично всі галузі знань. За масштабом існує повний спектр систем електронних бібліотек: 1) конкретного журналу або групи журналів; 2) електронна бібліотека окремого дослідницького колективу; 3) наукової установи, регіону, відомства; 4) національні/міжнародні [1, с. 16].

Функиії і технологї наукових електронних бібліотек. Усі перераховані вище властивості й особливості інформаційних ресурсів, колекцій i власне наукових електронних бібліотек визначають той факт, що вони можуть створюватися в самих різних варіантах і за архітектурою - від зосереджених до розподілених, від матеріалізованих до віртуальних, і за технологіями - окремі Web-сайти, системи баз даних, текстові системи, системи, засновані на інтеграції технологій [1, с. 16].

Основними функціями наукових електронних бібліотек $є$ :

- зберігання й актуалізація колекцій інформаційних ресурсів;

- забезпечення доступу користувачів до колекцій;

- формування колекцій (оцифрування, реєстрація результатів спостережень й експериментів безпосередньо в процесі їх проведення тощо);

- інтеграція видавничих технологій і технологій формування колекцій;

- надання різних вбудованих або надбудованих сервісів, додатків, що перетворюють електронні бібліотеки в дослідницький полігон (віртуальна лабораторія, віртуальна обсерваторія тощо) [1, с. 15-16].

Абросимов А. Г. [1] зазначає, що особливості наукових електронних бібліотек проявляються не в самому наборі функцій, а в специфіці їх реалізації, що враховує властивості наукових інформаційних ресурсів і колекцій.

Технології, що використовуються для реалізації функцій наукових електронних бібліотек, досить різноманітні:

- для формування колекцій електронних версій друкованих видань (бібліотечні технології і стандарти каталогізації; технології текстового пошуку, сучасні моделі пошуку, індексування тексту, зображень, аудіо, відео);

- для доступу до ресурсів електронних бібліотек (Web-технології, платформа XML; технології забезпечення інтероперабельності; різні уявлення метаданих (стандарти XML, DC, стандарти годинних); протоколи глобального доступу до інформаційних ресурсів (зокрема, до розподілених ресурсів); 
- для формування колекцій: методи, моделі та архітектури інтеграції неоднорідних інформаційних ресурсів; технології баз даних, бази даних на основі XML-технологій; об'єктні технології і багато іншого [1, с. 17].

Можливий список технологій, які можуть бути використані для створення наукових електронних бібліотек, який охоплює такі напрямки:

1) протоколи глобального доступу до інформаційних ресурсів, тобто забезпечення доступу до інформаційних ресурсів всієї світової спільноти і самими різними способами;

2) забезпечення інтероперабельності, у тому числі, можливість надання різних сервісів, що перетворюють електронні бібліотеки в дослідницький майданчик;

3) інтеграція неоднорідних інформаційних ресурсів, забезпечення складних взаємозв'язків між ресурсами різних видів. Це вказує на тенденцію до використання вільно поширюваного програмного забезпечення, використання технологій відкритих систем, що дозволяють включитися в розробку програмного забезпечення й інтерфейсів наукової електронної бібліотеки в цьому зацікавленій спільноті [1, с. 17].

Однією з перешкод на шляху розвитку електронних бібліотек і ще одним серйозним викликом для спільноти фахівців і дослідників у цій галузі є відсутність узгодженої архітектури електронних бібліотек, тим більше сервіс-орієнтованої архітектури. На жаль, з точки зору надання послуг кінцевому користувачеві нині немає повноцінних реалізацій електронних бібліотек, які дозволяли б надати складну композитну послугу, скажімо на основі технологій веб-сервісів або інших технологій, що дозволяють творцям електронної бібліотеки звернутися до окремих сервісів уже існуючих електронних бібліотек і запропонувати своєму користувачеві ту складну послугу, яка йому потрібна [13].

Абросімов А. Г. підкреслює, що перспективними напрямами розвитку наукових електронних бібліотек є: розробка змісту метаданих для конкретних колекцій; семантична інтеграція неоднорідних колекцій; методи індексування і пошуку нетекстових інформаційних ресурсів; технології створення і підтримки наукових електронних колекцій; використання стандартів і технологій XML для представлення й опису інформаційних ресурсів; методологія й інструментальні засоби розробки електронних бібліотек [1, с. 17]. 
Виділимо особливості наукових електронних бібліотек відповідно до наведених критеріїв.

1) за тематикою наявних ресурсів - електронні бібліотеки для певної галузі знань чи наукового напряму; універсальні; особисті архіви відомих учених;

2) за масштабом - електронна бібліотека певного регіону, держави; бібліотека для підтримки окремого періодичного видання або групи видань; бібліотека окремої наукової/освітньої установи;

3) за технологіями - окремі Веб-сайти, бази даних чи системи текстового пошуку, що засновані на інтеграції технологій;

4) за архітектурою - від матеріалізованих до віртуальних, від зосереджених до розподілених [10].

Президент України у своєму Посланні до Українського народу, ще у 2010 році, поставив завдання щодо створення Національної електронної бібліотеки і зазначив, що важливим проектом має стати створення Національної електронної бібліотеки, яка б об’єднала наукові, освітні, університетські та музейні ресурси в одну мережу. Також, у 2011 році Президентом було підтверджено план щодо створення електронної бібліотеки, а у березні 2012 року, знову анонсовано створення, поряд із системою електронного урядування, національної мережі електронних бібліотек. Тобто, важливими є конкретні кроки з розбудови потужної національної електронної бібліотечної системи [4].

У 2009-2011 pр. в Інституті інформаційних технологій і засобів навчання НАПН України (ІІТЗН НАПН України) під час виконання НДР «Науковоорганізаційні засади забезпечення функціонування єдиного інформаційного простору бібліотек наукових і навчальних закладів АПН України» [3] була створена електронна бібліотека НАПН України (Електронна бібліотека НАПН України), яка розміщена за адресою http://lib.iitta.gov.ua. Сторінка цієї бібліотеки представлена на рис. 1. 


\section{Електронна бібліотека Eêprints НАПН України \\ Перегляд за установою та за роками \\ Будь ласка, виберіть значення для перегляду із списку нижче. \\ - Національна академія педагогічних наук України (546) \\ - Інститут педагогіки (1) \\ - Інститут інформаційних технологій і засобів навчання (545) \\ - Відділ комп'ютерно-орієнтованих систем навчання і досліджень (101) \\ - Відділ електронних інформаційних ресурсів і мережних технологій (107) \\ - Відділ інформатизації навчально-виховних закладів (86) \\ - Відділ дослідження і проектування навчального середовища (71) \\ - Інформаційно-аналітичний відділ педагогічних інновацій (72) \\ - Відділ лабораторних комплексів засобів навчання (99) \\ Електронна бібліотека НАПн Українибабуетьса на EPrints 3 - вільно розповсюджуване програмне забезпеченна, розроблене в Школі електроніки та комп'ютернихнаук при Університеті Саутгемптон Англіа.Більш детальна інформаціа та програмне забезпеченна.}

Рис. 1. Сторінка наукової Електронної бібліотеки НАПН Украӥни

Станом на 02.02.2013 р. до Електронної бібліотеки НАПН України вже внесено 546 публікацій наукових працівників, також, показано кількість публікацій, які внесені співробітниками різних відділів Інституту [5].

Інформаційні ресурси, що зберігаються в Електронній бібліотеці НАПН України, можна переглядати за такими полями: перегляд за роками та авторами; перегляд за темою класифікатора та авторами; перегляд за науковою установою, відділом, роками та авторами; перегляд за автором (співавтором), за типом ресурсу та роками.

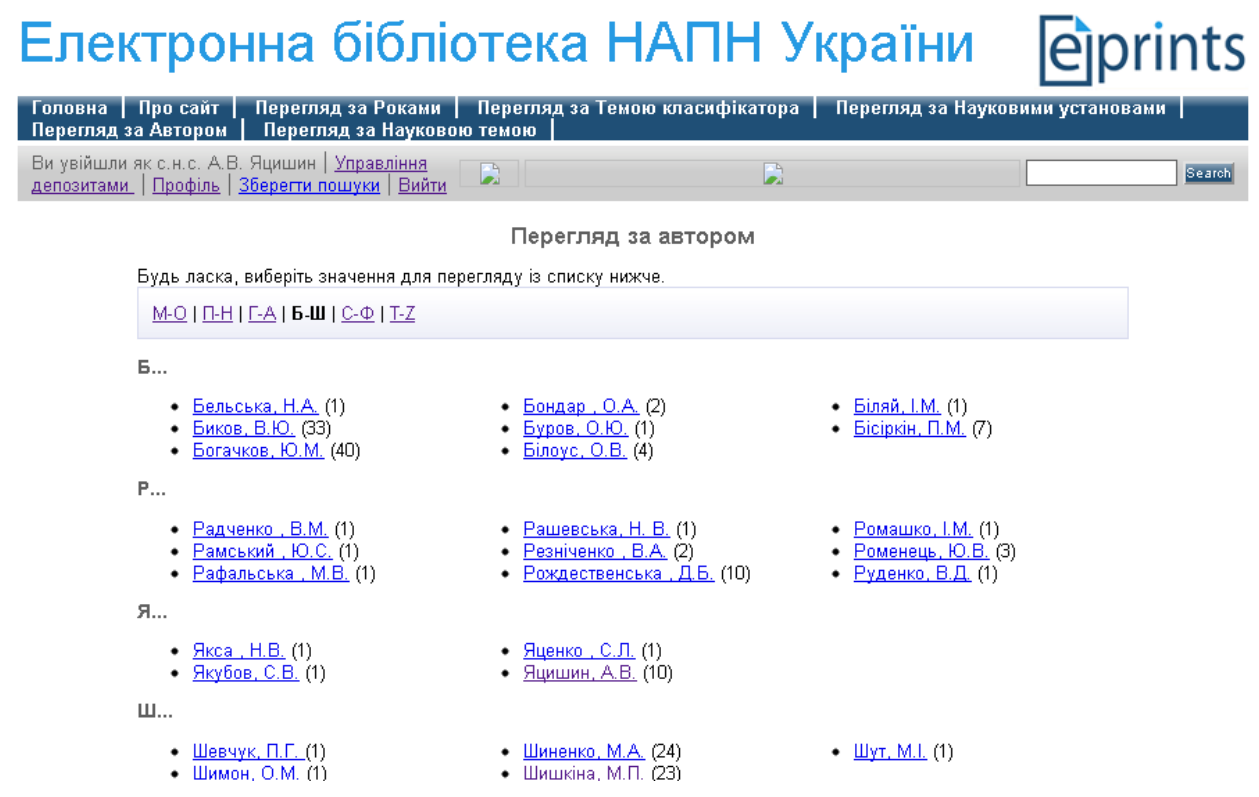

Рис. 2. Перегляд за автором на сайті Електронної бібліотеки НАПН Украӥни 
Будь-який користувач, відкривши сайт Електронної бібліотеки НАПН України, може переглянути вміст сховища. На рис. 3. показано опис публікації певного автора (Яцишин А. В.), що розміщено в Електронній бібліотеці НАПН України, дану публікацію, як і всі інші, можна вільно завантажити зі сховища бібліотеки. Також, $\epsilon$ можливість підписатися на списки розсилання, створювати і зберігати пошуки. Користувач-депонент - має права мінімального користувача і додатково за ним закріплена робоча область, куди він може завантажувати свої ресурси, заповнювати необхідні поля опису цих ресурсів (вказується автор ресурсу, електронна адреса, установа, назва ресурсу, анотація та ключові слова вносяться українською й англійською мовами, далі описується ресурс: статус публікації, дата, місце та журнал, кількість сторінок та ін.) і передавати їх до робочої області на розгляд, перед тим як ресурси завантажити до сховища Електронної бібліотеки НАПН України [6].

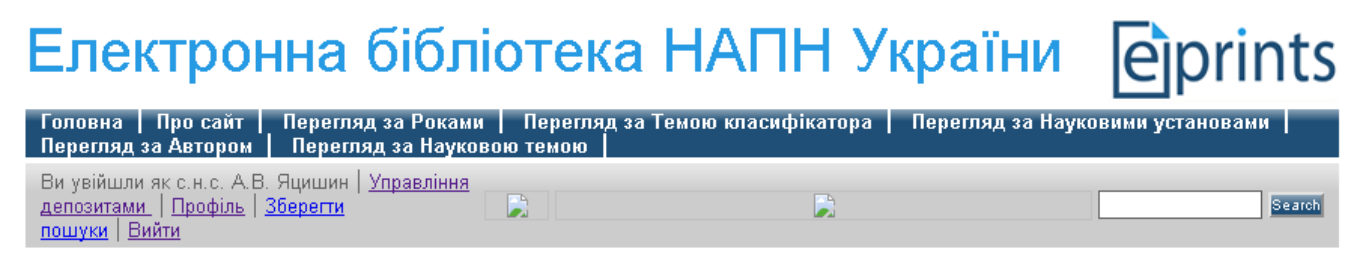

Соціально-психологічні аспекти впровадження електронної бібліотеки Національної академії педагогічних наук України

Яцишин, А.В. (2012) Соціально-психопоеінні аспекти впровадження електоонної бібліотеки Національної академіі педаеоеинних наук Уқрайни Інформаційні технології і засоби навчання, 3 (29). ISSN 2076-8184

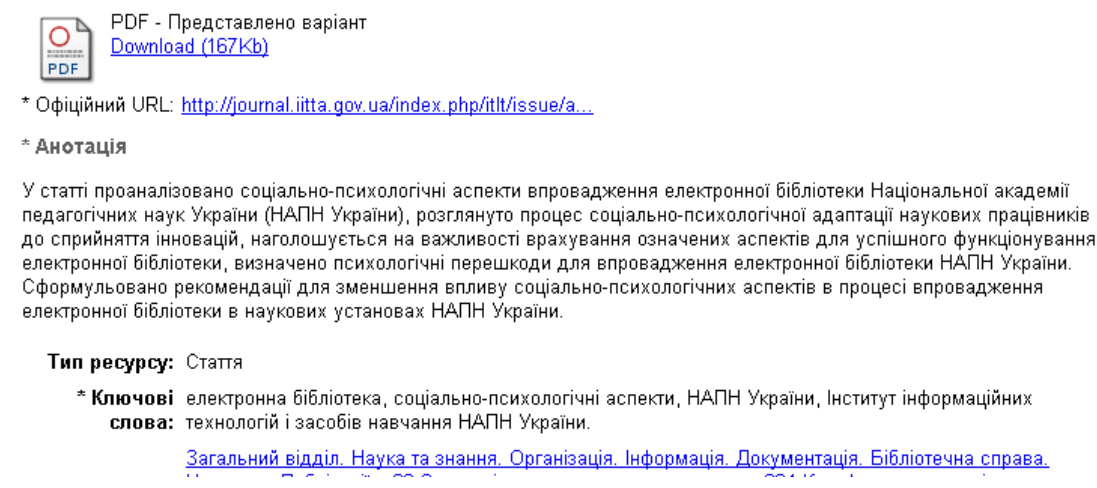

Рис. 3. Опис публікаиії певного автора в Електронній бібліотеці НАПН України

Після впровадження Електронної бібліотеки НАПН України в Інституті у 20112012 рр., було зроблено низку доповнень і налагоджень. Вдала апробація надала можливість продовжити науково-дослідну роботу у 2012-2014 pp. зі створення мережі електронних бібліотек установ НАПН України, до яких входять такі установи: Інститут педагогіки, Інститут обдарованої дитини, Інститут спеціальної педагогіки, Інститут вищої освіти, Інститут професійно-технічної освіти, ДВНЗ «Університет 
менеджменту освіти», Державна науково-педагогічна бібліотека України ім. В. О. Сухомлинського та ін.

Протягом наступних років передбачається створення єдиного наукового інформаційного простору електронних бібліотек установ НАПН України, який включає до себе мережу електронних бібліотек. Мережа складається із серверів (вузлів) електронних бібліотек, а також їі центрального сервера (центрального вузла). На цей сервер покладені завдання підтримки роботи віртуальних бібліотек, а також функції керування мережею електронних бібліотек установ НАПН України. Віртуальні бібліотеки $\epsilon$ незалежними складовими частинами центрального бібліотечного сервера мережі електронних бібліотек, які розмежовані правами доступу й об'єднані єдиним каталогом електронних ресурсів і користувачів мережі [12].

Кожній установі НАПН України може бути виділена робоча область (віртуальна бібліотека на сервері ІІТЗН НАПН України), яку вони заповнять своїми інформаційними ресурсами. Така робоча область включає сегмент єдиного каталогу мережі електронних бібліотек установ НАПН України, сегмент єдиного каталогу цієї мережі, а також необхідні сервіси керування віртуальною бібліотекою [12]. Мережа електронних бібліотек НАПН України дозволить докорінно змінити сам принцип інформаційного обслуговування користувачів: звертаючись до системи, вони будуть одержувати не лише посилання (бібліографію чи реферат) на наявний електронний документ, але і сам документ (повну копію оригінальної статті, автореферат дисертації, графічний образ картини чи технічного креслення, відеозапис проведеного дослідження тощо) [12].

Отже, із зазначеного вище можна зробити висновки, що наукові електронні бібліотеки охоплюють специфічну предметну галузь, а з цим і пов'язані особливі вимоги до них; їх колекції інформаційних ресурсів є специфічними за змістом i неоднорідними; до наукових електронних бібліотек вбудовані специфічні сервіси, завдяки яким вони можуть бути використані не тільки як джерело інформаційних ресурсів, але i як майданчик для наукових досліджень. Створення мережі електронних бібліотек дозволить по-новому організувати робоче місце науковця шляхом реалізації можливості колективної роботи і навчання, створення колективних віртуальних середовищ. Поряд з тим буде знижено вартість наукових досліджень за 
рахунок колективного використання інформаційних ресурсів [12]. Тобто, мережа електронних бібліотек НАПН України, на думку автора, займе чільне місце у науково-освітньому просторі України і стане потужним ресурсом для навчальних цілей i проведення наукових досліджень у галузі педагогічних наук i допоможе представити значний науково-педагогічний доробок України у світовому інформаційному просторі.

\section{Список використаних джерел}

1. Абросимов А. Г. Электронные библиотеки научных и образовательных ресурсов: учебно-методическое пособие / Абросимов А. Г., Лазарева Ю. И. Казань : КГУ, 2008. - 78 с.

2. Арнаутов С. А. Роль и место виртуальных цифровых библиотек в Интернете (на примере Российской академии наук) [Электронный ресурс] / Арнаутов С. А. / Сб. докладов 3-й Всероссийской научной конференции «Электронные библиотеки: перспективные методы и технологии, электронные коллекции» (Петрозаводск, 11-13 сентября 2001 г.). - КарНЦ РАН. - С. 46-50.

3. Веб-сайт Інституту інформаційних технологій i засобів навчання НАПН України [Електронний ресурс]. - Режим доступу : http://www.ime.eduua.net/index.html. - Дата доступу 21.01.2013.

4. Використання потенціалу електронних бібліотек та відкритого доступу для українських освіти і науки [Електронний ресурс] / Веб-сайт Національного інституту стратегічних досліджень при Президентові України. - Режим доступу : http://www.niss.gov.ua/articles/877/. - Дата доступу 11.02.2013.

5. Електронна бібліотека НАПН України [Електронний ресурс]. - Режим доступу : http://lib.iitta.gov.ua. - Дата доступу 25.01.2013.

6. Електронні бібліотечні інформаційні системи наукових і навчальних закладів : монографія [Електронний ресурс] / [Іванова С. М., Новицький О. В., Савченко 3. В., Яцишин А. В. та ін. ] / за наук. ред. В. Ю.Бикова, О. М. Спіріна. - К. : Педагогічна думка, 2012. - Режим доступу : http://lib.iitta.gov.ua/606/. - Дата доступу 01.12.2012.

7. Іванова С. М. Тендеції використання електронних бібліотек в наукових і навчальних закладах (зарубіжний і вітчизняний досвід) [Електронний ресурс] 
/ С. М. Іванова // Інформаційні технології і засоби навчання. - 2011. - №3 (23). -Режим доступу до журналу : http://journal.iitta.gov.ua/index.php/itlt/issue/view/42.

8. Когаловский М. P. Особенности научных электронных библиотек. [Электронный ресурс] // Тезисы докладов научной конференции, посвященной 10-летию РФФИ «Электронные библиотеки и информационное обеспечение научной деятельности», Москва, 25-26 ноября 2002 г. Российский фонд фундаментальных исследований, Центр фотохимии РАН, 2002. - Режим доступа : http://www.elbib.ru/content/methodology/xml/sci_DL.pdf. - Дата доступу 25.12.2012.

9. Лапо П. М. Введение в электронные библиотеки [Электронный ресурс] / П. М. Лапо, А. В. Соколов. - Электрон. Текстовые данные. - Режим доступа : http://www.iatp.by/handouts/library/e-libraries/2-16.htm. - Дата доступу 10.12.2012.

10. Научно-методическая поддержка разработки научных электронных библиотек [Электронный ресурс] / [Акимов С. И., Елизаров А. М., Ершова Т. В. и др.] // Электронные библиотеки. Российский научный электронный журнал. - 2005 T. 8 - Вып. 1 - Режим доступа: http://www.elbib.ru/index.phtml?page=elbib/rus/journal-/2005/part1/AEEKFH. - Дата доступу 10.12.2012.

11. Савченко 3. В. Формування і використання інформаційних електронних науково-освітніх ресурсів [Електронний ресурс] / 3. В. Савченко // Інформаційні технології і засоби навчання. - 2010. - №4 (18). - Режим доступу до журналу : http://www.ime.edu-ua.net/em.html.

12. Спірін O. М. Концептуальні засади побудови мережі електронних бібліотек Національної академії педагогічних наук України [Електронний ресурс] / О. М. Спірін, С. М. Іванова, О.В.Новицький // Інформаційні технології і засоби навчання. - 2012. - № 5 (31). - Режим доступу : http://journal.iitta.gov.ua.

13.Хохлов Ю. Е. О месте электронных библиотекв информационном обществе [Электронный ресурс] / Хохлов Ю.Е. // Электронные библиотеки. Российский научный электронный журнал. - 2006. - Т. 8 (2) - Режим доступа : http://www.elbib.ru/index.phtml?page=elbib/rus/journal/2005/part2/Hohlov. 
14. Яцุищин A. В. Впровадження електронної бібліотеки Національної академії педагогічних наук України: перші кроки / А. В. Яцишин // Матеріали Міжнар. наук.-практ. інтернет-конф. «Україна наукова» (Київ, 21-23 груд. 2011 р.). - К., 2011. - C. 61-65.

15. Яциишин A. B. Соціально-психологічні аспекти впровадження електронної бібліотеки НАПН України [Електронний ресурс] / А. В.Яцишин // Інформаційні технології і засоби навчання. - 2012. - №3 (29). - Режим доступу : http://journal.iitta.gov.ua/index.php/itlt/issue/view/51.

Матеріал надійшов до редакції 12.02.2013 р.

\section{МЕСТО И РОЛЬ СЕТИ ЭЛЕКТРОННЫХ БИБЛИОТЕК УЧРЕЖДЕНИЙ НАПН УКРАИНЫ В НАУЧНО-ОБРАЗОВАТЕЛЬНОМ ПРОСТРАНСТВЕ}

Яцишин Анна Владимировна, кандидат педагогических наук, старшый научный сотрудник, докторант, Институт информационных технологий и средств обучения НАПН Украины, anna13.00.10@gmail.com.

\section{Аннотация}

В статье проанализированы критерии оценки научных электронных библиотек, рассмотрены различные взгляды ученых на перечень этих критериев. Описано, что критериями оценки электронной библиотеки могут служить: пользователи и их информационные потребности, характер информационных ресурсов, функциональные возможности, характер и содержание информационных ресурсов. Определены особенности, требующие особого подхода к разработке научных электронных библиотек. Указано, что создание сети электронных библиотек учреждений НАПН Украины является одним из приоритетных направлений развития науки и образования, и первоочередной задачей главы государства. Коротко представлено уже созданную Электронную библиотеку НАПН Украины. Определено место и роль сети елеронных библиотек учреждений НАПН Украины в научнообразовательном пространстве.

Ключевые слова: электронная библиотека, критерии оценки, особенности электронных библиотек, НАПН Украины, Институт информационных технологий и средств обучения НАПН Украины. 


\section{THE ROLE OF THE E-LIBRARIES NETWORK OF THE NAPS OF UKRAINE IN SCIENTIFIC AND EDUCATIONAL SPACE}

Anna V. Yatsishin, $\mathrm{PhD}$ (pedagogical sciences), doctoral student, Institute of Information Technologies and Learning Tools of NAPS of Ukraine, Kyiv, e-mail: anna13.00.10@gmail.com

\section{Resume}

In the article the criteria for the evaluation of scientific e-libraries are analyzed, the different views of scientists on the list of the criteria are considered. It is described that the criteria for the e-library evaluation can serve the next ones: users and their information needs, the nature of information resources, functionality, nature and content of information resources. The features that require a special approach to the development of scientific elibraries are defined. It is stated that the creation of the e-libraries network of the institutions of NAPS of Ukraine is one of the priority directions of science and educational development, a priority of the state. The e-library of NAPS of Ukraine is presented briefly. The role of the e-libraries network of the institutions of NAPS of Ukraine in the scientific and educational space is defined.

Keywords: e-library, evaluation criteria, NAPS of Ukraine, Institute of Information Technologies and Learning Tools of NAPS of Ukraine.

\section{REFERENCES (TRANSLATED AND TRANSLITERATED)}

1. Abrosimov A. G. Digital libraries of scientific and educational resources: a teaching aid / Abrosimov A. G., Lazareva Ju. I. - Kazan' : KGU, 2008. - 78 p.

2. Arnautov S. A. The role and place of virtual digital libraries on the Internet (for example, the Russian Academy of Sciences) [online] / Arnautov SA / Sat. Reports 3rd Scientific Conference "Digital Libraries: Advanced Methods and Technologies, Digital Collections" (Petrozavodsk, 11-13 September 2001 ). - KarNC RAN. - P. $46-50$.

3. Website of the Institute of Information Technologies and Learning Tools of NAPS of Ukraine [online]. - Available from: http://www.ime.edu-ua.net/index.html. - Date 21.01.2013.

4. Using the potential of digital libraries and open access for Ukrainian Education [online] / Website of the National Institute for Strategic Studies under the President 
of Ukraine. - Available from: http://www.niss.gov.ua/articles/877/. - Date 11.02.2013.

5. Digital library of NAPS of Ukraine [online]. - Available from: http://lib.iitta.gov.ua. - Date 25.01.2013.

6. Digital library information systems of research and educational establishments: a monograph [online] / [Ivanova C. M., Novytskyi O. V., Savchenko Z. V., Yatsyshyn A. V. ta in. ] / za nauk. red. V. Yu. Bykova, O. M. Spirina. - K. : Pedahohichna dumka, 2012. - Rezhym dostupu : http://lib.iitta.gov.ua/606/. - Date 01.12.2012.

7. Ivanova S. M. Trends in the use of digital libraries for scientific and educational institutions (foreign and domestic experience) [online] / S. M. Ivanova // Information Technologies and Learning Tools. - 2011. - №3 (23). - Available from: http://journal.iitta.gov.ua/index.php-/itlt/issue/view/42.

8. Kogalovskij M. R. Features of scientific digital libraries. [online] / / Proceedings of the scientific conference devoted to the 10th anniversary of RFBR "Digital libraries and information support of scientific activities", Moscow, November 25-26, 2002, the Russian Foundation for Basic Research, Photochemistry Center of RAS, 2002. Available from: http://www.elbib.ru/content/methodology/xml/sci_DL.pdf. - Date 25.12.2012.

9. Lapo P. M. Introduction to digital libraries [online] / P. M. Lapo, A. V. Sokolov. Electron. text data. - Available from: http://www.iatp.by/handouts/library/elibraries/2-16.htm. - Date 10.12.2012.

10. Scientific and methodological support for the development of scientific digital libraries [online] / [Akimov S. I., Elizarov A. M., Ershova T. V. i dr.] // Electronic libraries. Russian scientific e-journal. - 2005 - T. 8 - Vyp. 1 - Available from: http://www.elbib.ru/index.phtml-?page=elbib/rus/journal-/2005/part1/AEEKFH. Date 10.12.2012.

11. Savchenko Z. V. Formation and use of electronic information science and educational resources [online] / Z. V. Savchenko // Information Technologies and Learning Tools. - 2010. - №4 (18). - Available from: http://www.ime.eduua.net/em.html.

12. Spirin O. M. Conceptual framework for designing network of electronic libraries of the National Academy of Pedagogical Sciences of Ukraine [online] / O. M. Spirin, 
S. M. Ivanova, O. V. Novytskyi // Information Technologies and Learning Tools. 2012. - № 5 (31). - Available from: http://journal.iitta.gov.ua.

13. Hohlov Ju. E. The place of digital libraries in the information society [online] / Hohlov Ju.E. // Electronic libraries. Russian scientific e-journal. - 2006. - T. 8 (2) Available from: http://www.elbib.ru/index.phtml?page=elbib/rus/journal/2005/part2/Hohlov.

14. Yatsyshyn A. V. Implementation of the electronic library of the National Academy of Pedagogical Sciences of Ukraine: first steps /A. V. Yatsyshyn // Proceedings Internat. scientific-practical. Internet conference. "Ukraine scientific" (Kyiv, 21-23 Dec. 2011). - K., 2011. - P. 61-65.

15. Yatsyshyn A. V. Social and psychological aspects of the Digital Library of NAPS of Ukraine [online] / A. V. Yatsyshyn // Information Technologies and Learning Tools. - 2012. - - №3 (29). $\quad$ - $\quad$ Available from: http://journal.iitta.gov.ua/index.php/itlt/issue/view/51. 